\title{
Chapter 1 \\ Introduction: Advances in Research on Shared Physical Custody by Interdisciplinary Approaches
}

\author{
Laura Bernardi and Dimitri Mortelmans
}

\begin{abstract}
This introductory chapter provides the rationale for adopting an interdisciplinary approach to study the implications of shared physical custody arrangements for families and their members. The Chapter gives a rapid overview of the current state of the literature on shared physical custody in the legal, sociological and psychological literature and highlights the uncertainties and controversial aspects still open to exploration in this field. It addresses the specific research needs in order to move forward from the current situation, where evidence on shared physical custody produce results that are scattered across disciplines and hard to compare across contexts. It concludes by arguing that the complexity of shared physical custody implications in terms of health, educational, relational and living standards requires research from different disciplinary fields in order to agree on a comprehensive theoretical perspective, standardize definitions and collect longitudinal and comparable data on the custody arrangements and their normative environments.
\end{abstract}

Keywords Interdisciplinary $\cdot$ Care arrangements · Comparative $\cdot$ Longitudinal · Shared custody

\footnotetext{
L. Bernardi $(\bowtie)$

LIVES Centre, Swiss Centre of Expertise in Life Course Research and Institute of Social Sciences, University of Lausanne, Lausanne, Switzerland

e-mail: laura.bernardi@unil.ch

D. Mortelmans

Centre for Population, Family and Health (CPFH), University of Antwerp, Antwerp, Belgium

e-mail: dimitri.mortelmans@uantwerpen.be
} 


\subsection{An Interdisciplinary Approach to Shared Physical Custody}

Shared physical custody (SPC) ${ }^{1}$, the care arrangement in which a child lives from $30 \%$ to $70 \%$ of the time with each parent after their separation or divorce, has been on the rise in most Western regions in the last two decades (Smyth 2017). Prevalence and incidence of SPC vary substantively by context though. While the percentage of SPC among divorced and separated parents grew from $12 \%$ to $50 \%$ between 1989 and 2010 in some contexts like in the US state of Wisconsin (Meyer et al. 2017), it remains mostly a minority arrangement, ranging from $12 \%$ in the UK to $40 \%$ as in Belgium and Quebec in 2017 (Steinbach et al. 2020).

The emergence of SPC can be related to increasing aspirations to gender equality among parents, where mothers are increasingly active on the labour market and engaged in demanding professional careers as well as wanting equality in housework shares, while, at the same time, fathers want to care more for their children (Goldscheider et al. 2015; Hook 2016; Westphal et al. 2014). The daily time that both residential and non-residential fathers report to spend in childcare increased substantially over the last decade (Klünder and Meier-Gräwe 2018; SchoppeSullivan and Fagan 2020), indicating that many separated fathers increasingly engage with their children. The introduction of more gender-neutral family policies facilitating active fatherhood (e.g., longer parental and paternal leave Thevenon 2011) contributed to this shift (Bartova and Keizer 2020).

In addition, shared physical custody is also seen as a way to counteract the negative consequences of separation and divorce for children. Several social and psychological studies addressing this issue have pointed out the multiple risks of children when losing contact with one of their parents (in the large majority of cases fathers). Economic and psychological hardships would threaten children's adjustment, their future development and life chances (Amato 2000, 2010; Amato and Cheadle 2005; Härkönen et al. 2017).

Last, and relatedly to these societal developments and scientific evidence, the exponential increase in SPC care arrangements depends on changes in the principles guiding courts' and judges' decisions. These have shifted from an implicit preference for mothers' physical custody, to an encouragement to prefer shared physical custody or to hold a presumption in its favor (Goubau 2009). Change started with shared legal custody granting unmarried parents, as well as married ones, equal say in important decisions concerning child development and living conditions (health, education, residence and religion). The demand for shared physical custody was a logical next step as the shared responsibility of legal custody would have to match the parental experience of raising the children. Nowadays, legal custody is

\footnotetext{
${ }^{1}$ Such arrangement is also known as joint physical custody, shared parenting, shared (dual) residence; or in French-speaking countries as résidence alternée (alternating residence). From now on in this volume we define it as shared physical custody as this is the less ambivalent term among such alternatives.
} 
widespread but it is not always followed up by shared physical custody despite the strong advocacy it has received.

The key turning point in shared physical custody occurred when juridical guidelines for decisions regarding post separation custody arrangements began to be constructed as if the "best interest of the child" was something different from the interest of the child's primary caregiver (the mother until then). The notion is tricky though as the best interest of the child as an autonomous person seems to be at odds with the fact that the child depends on at least one of its parents and the interest of both parents may not overlap with the child's interests. When parents disagree on custody arrangements, judges often have to evaluate a complex set of factors in order to identify the best interest of the child.

The societal and legal debate on the best interest of the child is often informed by ideological positions (Kruk 2012). On the one hand, the need for the continuity of the relationship with both parents has been contrasted to the idea that mothers are the primary carers and therefore shall have priority in shared physical custody. On the other hand, the issue of equal treatment among parents questions the moral basis on which fathers are charged for financing children that they could visit and not live with. Father's movement have been vocal about more equality, to an extent the issue has come to dominate both the legal and political landscape. Fathers' rights groups identified the fact of ensuring justice and equality between parents with the presumption of a post separation SPC, possibly a 50/50 one, unless the child's wellbeing suggested otherwise (Spruijt and Duindam 2002).

As a consequence, in the last few decades, maintaining the relationship with both parents after the marital separation or divorce through co-parenting has evolved into a political as much as an emotional debate (Harris-Short 2010). The idea is that both parent-child relationships shall continue despite the fact that the conjugal relationship has broken apart, replacing the non-substitutability of the mother as primary carer. Debates are still hot on whether this is also the case for babies and toddlers, in case of absent or conflictual communication among parents and in cases of severe precarious living conditions. In addition, parents' ability to establish cooperative co-parenting after separation seems to clash, at least in the short term, with the fact that they have put an end to their alliance as a couple. Newly published research shows, for instance, that it is not SPC that may benefit adolescent children but rather the family characteristics that led them to prefer such arrangements (Steinbach et al. 2020). As a matter of fact, empirical evidence is still to be solid and reliable, as often based on heterogeneous studies involving selective populations of higher educated and low-conflict parents or smaller scale studies, as we will discuss in the next section.

And yet, when evaluating the reasons leading to prefer a care arrangement for children or its consequences, we are immediately confronted with the complexity of mechanisms at work. Reasons can be based on parents' or judges' belief that continuity shall be privileged with the pre-separation care habits, or on the possibilities of offering the child a better living standard, or, still, on the child preference for spending more time in one household rather than the other (not changing the social environment, not getting along with possible step parents and siblings etc.). 
Outcomes are also a multidimensional realm ranging from short term cognitive and emotional health, physical health, economic and housing conditions, educational and relational opportunities to longer term consequences including life course development of children and their success in adult life. With such a complex picture, defining what is in the child's best interest seems to be a challenging task, where priorities shall be established and shorter and longer outcomes weighed against each other. A comprehensive theoretical perspective addressing the complexity of such mechanisms is currently missing, contributing to a wealth of diverging empirical results concerning determinants and consequences of SPC.

In addition to the lack of clarity in whether SPC is desirable and under what circumstances, there is also some fuzziness in the definition on what constitutes enough custodial time so that it can be defined as "shared". While 50\% would correspond to equal sharing, among professionals, policy makers and social scientists the interpretation of the term "shared" converges on something in between the time accorded for usual visiting rights to a non-residential parent (usually every two weekends and half of school holidays) and the full custody. Mostly, in research and practice, $30-50 \%$ of the time is considered sufficiently substantial to be SPC, with a primary and a secondary carer when time is not exactly equal (Meyer et al. 2017). The development over time of such percentage is unclear though. Couples may be constantly re-evaluating and changing it or even suspending it for a period without any chance for researchers to track such dynamics too closely.

Against this background of contradicting theoretical predictions, diverging empirical evidence and lack of precise definitions of care arrangements forms of post separation families involving children, this volume gives a multidisciplinary view of SPC, hoping to contribute to a substantive and constructive research dialogue to advance knowledge in this domain and offer a better guidance both for future research and for legal and social policy professionals. Psychological adjustment and development studies address the short and longer term risks for children and parents involved in such arrangements. At the same time, sociological and demographic awareness include attention to the heterogeneity of processes across social groups and gender. In addition, shifting care arrangements are looked at in terms of changes for family relationships but also, in the longer run, for family diversity and the distribution of family forms in the society. The dynamics of obligations and interdependency of individuals' support beyond the nuclear family is affected by children's care and residential arrangements. Both legal and social policy scholarships have to be involved in the definition of what the boundaries of the state intervention are in such dynamics. Similarly, there is a need to clearly indicate the empirical basis and the guiding value principles shaping such intervention.

\subsection{Insights on Shared Physical Custody Outcomes}

The field that covers the outcomes of shared physical custody is characterized by a huge number of studies and an almost equal number of reviews summarizing these studies. Some of these reviews focus on the outcomes for children (Baude et al. 
2019; Braver and Votruba 2018), others take parents into account (Fransson et al. 2016). Some aim specifically at informing practice (e.g. the legal field: Nielsen 2015), while others only focus on empirical evidence (Nielsen 2018b; Steinbach 2019). And finally, meta-analyses (Baude et al. 2016; Bauserman 2012) are developed next to classic literature overviews (Nielsen 2014b). These meta-analyses are important since they allow to compare the (often small) effect sizes. The analyses also show the direction and size of the effects under study. The huge amount of reviews shows that this is a controversial topic that raises great concerns (especially concerning children) and touches basic societal processes like parenthood and basic human attachment.

In this introduction, we do not aim to give a review of all reviews. Nor do we want to present a new all-encompassing literature review on the empirical evidence on outcomes of shared physical custody. We rather aim to point at the research interests that have been developed in this field to provide the reader with some directions through the literature. As this book aims to give new insights in shared physical custody from an interdisciplinary perspective, we will point to research interests from psychology, demography, sociology and law research. The fields of psychology and sociology have produced knowledge on the outcomes of SPC and the potential gains and losses for both children and parents adopting this custody regime. Demography adds a focus on gendered union and fertility dynamics that may derive from different custodial practices (e.g. van der Wiel et al. 2020). Law research on the other hand looks for ways to apply these results in legal procedures that mould the outcomes in the best possible way. For more detailed overviews in these fields, we refer to Chaps. 2, 3 and 4 where more elaborate disciplinary introductions are provided.

The overall burning question in the literature is whether or not the outcomes for children and parents are better when shared physical custody is chosen over single physical custody. Multiple factors have been explored to study a wide variety of possible outcomes. As we will discuss, parental education and income are the most important factors identified in this field and wellbeing is the outcome that received the most attention. Baude et al. (2016) and Nielsen (2018b) classify children's outcomes in five broad categories: (1) general adjustment or cognitive outcomes, (2) emotional or psychological adjustment, (3) behavioural adjustment, (4) social adjustment, and (5) family relations. In all these domains, results point to a general tendency of positive outcomes on children in joint physical custody (except in conflictual or violent situations which we will elaborate on later). Even though effects are usually small, they point to a higher wellbeing of children in shared care arrangements compared to sole physical custody. Mental health of children is better (e.g. Bergström et al. 2014), stress measures turn out to be lower (e.g. Turunen 2017) and their self-esteem is higher (e.g. Bastaits and Mortelmans 2016). Also behavioural and health components turn out to score better in shared physical custody: risk behaviour is lower than children in sole physical custody (e.g. Carlsund et al. 2012) and the children in joint physical custody tend to have less health related problems (Fabricius and Luecken 2007). 
When family relations are concerned, the focus lies exclusively on the bond with the father as traditional custody arrangements entailed living with the mother and visiting the father (e.g. once every two weeks). Shared physical custody almost automatically implies an increased contact with the father (Bauserman 2012; Cheadle et al. 2010; Westphal et al. 2014). This increased presence in the lives of children also results in closer bonds between the father and his children (Spruijt et al. 2004). The higher contact intensity also leads to better wellbeing in children after divorce (Bastaits and Pasteels 2019). But despite the positive outcomes in the literature, Poortman (2018) warns for a selection effect as pre-divorce involvement matters more to outcomes for children than the custody arrangement in itself.

Not only positive outcomes for children are found, also parents with a shared custody arrangement show improved outcomes on many domains. In his meta review, Bauserman (2012) reports lower levels of conflict both reported from the fathers and the mothers side. Some studies on relitigation show that parents in SPC less often return to court than other ex-partners even though some studies have found no difference or opposite effects (Bauserman 2012). Also labour market related factors turn out to be more favourable among parents in SPC compared to lone parents (Bernardi and Mortelmans 2018). For mothers, SPC enables them to gain a better access to the labour market and to focus on their career when their child resides with the father (Kruyfhooft and Mortelmans 2011). Women no longer have the full 'second shift' (Hochschild and Machung 1989) leaving room for leisure time, repartnering and labour market choices (Sodermans et al. 2015; van der Heijden et al. 2016).

Throughout these results, three main topics stand out as dividing the specialists the most: the role of parental resources (education and income), the role of conflict and the potential harm of SPC for young children. In the remainder of this book, the reader will find many expressions of the dominance of these three leitmotivs. The first controversy concerns parental resources. Studies have shown that parents in joint physical custody turn out to be higher educated and have higher incomes (Nielsen 2015; Steinbach 2019). Comparable to the classic observation of Goode $(1962,1963)$ that divorce rates start with the avantgarde of the wealthy and the higher educated, also SPC is selective in its parental demographic background. Comparable to Goode, also SPC is also expected to become less selective when more ex-couples prefer this care regime (Sodermans et al. 2013). Despite the selection effect, income differences turn out to be more limited than expected and even when controlling for education or income, SPC is systematically more beneficial than sole custody (Nielsen 2018a).

For conflict, the general assumption is that the lack of destructive parental conflict (Cummings and Davies 2010) is a crucial determinant in the success of SPC. The first question again is whether or not there is a selection effect of lower conflict families into SPC. The meta-analysis of Bauserman (2012) suggests that studies more often report lower levels of conflict in SPC. These results are confirmed from both the father's and the mother's side. But again, as SPC is rising among divorced couples, the more important question is whether conflict is more detrimental for children's outcomes in high conflict SPC compared to good interparental contacts 
among ex-spouses. Here, the evidence points to a rather limited effect of conflict on children's outcomes, contrary to general belief (Nielsen 2017).

Nielsen (2018b) asserts that we need to take into account selectivity or at least try to go beyond income and conflict to see whether the outcomes are really better in SPC despite these two crucial factors. Garriga and Bernardi (2019) show that SPC can translate in an additional source of inequality among children of non intact families given that more disadvantaged children profit less of its benefits than advantaged children, all other things equal. Other recent studies show that it is much more important for children to have a good relationship with their parents and have authoritative parents (Bastaits and Mortelmans 2016; Sobolewski and Amato 2007). The selection effect is clear in countries that introduce increased possibilities for SPC but as the phenomenon spread across society, the effect of class is likely to wane.

The last domain of controversy concerns the appropriateness for SPC for very young children (toddlers and babies). This domain is probably the most heavily debated field in this literature leading to scientific woozles, i.e. the misrepresentation and misuse of research by advocacy groups for their own political purposes (Nielsen 2014c). A first observation to be made is that the number of studies with babies or toddlers is very limited (Nielsen 2014a). Second, specialists often refer to attachment theory, or at least old concepts from attachment theory like monotrophy (attachment related to a single caregiver) (Warshak 2018) to defend care regimes with one dominant care giver. Time spent with a parent is taken as a main indicator for attachment while social interaction and expression of affection and a parent's responsiveness are far more critical to a secure attachment of children (Main et al. 2011). This leads to a mother-centered perspective and prohibiting laws for (overnight) stays at the father's house (Lamb and Kelly 2001). Third, even though time spent with parents is taken as the point of departure, overnights are considered as more "salient" in the debate on negative consequences than the overall frequency of stays. Also here, little or no empirical evidence exists for this claim (Warshak 2018). In summary, at present studies showing negative effects of SPC on young children are not only limited in number, they are often also handicapped in their methodological rigour as a control group is often absent. It strengthens advocates of SPC at any age in their claim that there is no scientific proof that SPC would harm infants in their development (Warshak 2018).

\subsection{Research Needs}

As our short overview of the literature has shown, many uncertainties and controversies remain in this field. Psychologists and sociologists debate on consequences of SPC, law researchers debate the best way to incorporate the best interest of the child in custody laws incorporating the wishes of both parents. For future research, it is clear that both new theoretical and empirical work is necessary. The confusion for practitioners is great and courts decide in many directions on the lives of parents and 
children. This volume aims to shed new insights from psychology, law and sociology and collects the major new insights in the field.

One issue that the volume cannot resolve is the lack of good and representative data. In order to make progress in the field, new empirical research on nationally representative data is crucial to gain nuanced insights in the outcomes for both children and parents. Too often, the debate is on the border of an ideological fight between advocates and contestants of SPC. Positive results from one review are interpreted by the next review in an opposite way to prove the adversary effects of SPC (Smyth cited in: Nielsen 2018b). Not seldomly, research is done on small samples acquired with convenience sampling techniques.

Even though small scale studies (for an overview, see: Bauserman 2012) and qualitative inquiry (e.g. Markham and Coleman 2012) contribute to new insights on the processes and mechanisms involved in SPC arrangements, nationally representative surveys are necessary to obtain more reliable knowledge with valid conclusions for subpopulations under study and practical recommendations to be applied by field workers. Too often, small samples lead to insignificant or small effects sizes jeopardizing firm conclusions. Fortunately, several nationally representative surveys have already been used in the US (Stanford Custody Project - Maccoby et al. 1993), Sweden (ULF - Survey on Swedish Living Conditions - Fransson et al. 2016), Australia $^{2}$ (HILDA, LSAC \& LSSF - Cashmore et al. 2010), Belgium (DIF Divorce in Flanders - Bastaits and Mortelmans 2016), Switzerland (SHP - Swiss Household Panel, this volume) and the Netherlands (NFN - New Families in the Netherlands - van der Heijden et al. 2016).

Most studies are cross-sectional in design. Only some studies have a longitudinal set-up and even then, it usually concerns a two-wave follow-up study (Guidubaldi and Perry 1985; Solomon and George 1999). Except for the Australian panel studies (see above), these longitudinal studies are also rather small in sample size. This lack in longitudinal analyses is problematic as SPC is a highly dynamic process (Bastaits et al. 2018). Throughout the life course of children not only the care regime change, but also the outcomes of the custody arrangements are not stable. Custody arrangements get adapted as children age or as parents ask courts to make adaptions. Also, the arrival of new-borns in blended families can have an influence on the SPC of the older children.

A quick gain in longitudinal analyses can be found in the use of register data (see Claessens and Mortelmans, Chap. 7, in this volume). As fiscal data become increasingly available, tax reductions for SPC arrangements lead to official identifications of this care regime in governmental data. Being longitudinal by nature, register data can provide us with large scale samples with a wide variety in family forms. It can also take the linked lives of former partners into account and follow their life courses as they unfold. Even though legal requirements on data linkage are challenging and not all countries will allow to match data from population registers with fiscal

\footnotetext{
${ }^{2}$ HILDA - Household Income and Labour Dynamics in Australia; LSAC - Longitudinal Study of Australian Children; LSSF - Longitudinal Study of Separated Parents.
} 
registers, exciting and complex life course research on SPC becomes possible in some countries. As the advantages of large-scale longitudinal data without attrition are clear, the registers do not have any subjective measures on parents or children. Health outcomes might be measurable but other indicators like problematic child behaviour, insecure attachment, or parenting styles lie beyond the scope of the registers.

A last empirical issue is the lack of comparable data to start comparative crosscountry analyses. To our knowledge, only one large scale comparative study on 37 Western countries has been done, using WHO data (Bjarnason and Arnarsson 2011). The main problem is the availability of indicators on the custody arrangement of children in large, nationally representative (panel) surveys. A lot of classic household surveys take "living under the same roof" as a holy principle for household composition. In such case, everybody in a household is assumed to live in it full time. With more and more children living in two households, the classic household grid needs adaptation to encompass new family forms in all its complexity. Register data is also no solution for the lack of comparable studies as most of these registers cannot be combined in pooled international databases due to privacy regulations of most countries and the aforementioned difficulty in linking fiscal data with general population registers. Also, outcome measures need more standardisation. Even though several validated tests are used in several studies, there still is debate on which boundaries to take to identify SPC (see elsewhere in this book) or which indicators are the best to measure child and parental outcomes. We hope this book will contribute in standardizing indicators to take the longitudinal and comparative leap forward in the field of SPC.

\subsection{Outline of the Book}

Chapter 2, Thompson and Turunen is a much needed sociological and demographic perspective on shared physical custody which complements perfectly the psychological and legal scholarships about such family arrangements. The authors make a compelling analysis of the structural features that are specific of SPC families and their implications for family relationships and family dynamics. One important observation among others is that the nature of the relationship between (step)parents and (step)children, (step)siblings and (step)grandparents requires more explicit recognition than in intact families and solo families since each other's agendas and needs cross and shall be negotiated upon more frequently. Crucially related to these aspects are the transformations in the gendered division of labour and the gendered character of family life and the recursive positive loop between gender equity and shared custody. Not only more gender equal couples are more likely to adopt SPC in case of separation, but also children in alternate residence also means more gender equal work, leisure and family trajectories after separation than parents with solo custody. The chapter clearly shows how SPC has the potential to revolutionize the 
gender contract and concludes with a pledge to monitor the longer run implications for the conceptualization and representations of family and gender at large.

In Chapter 3, Emery presents an extensive overview of research from a psychological perspective. The chapter focuses on the wellbeing of children living in SPC. A first part in the chapter deals with defining SPC and brings up the question of the wide range of family forms in which children live after the break-up of their parents. Defining SPC relies on determining a minimum amount of time that children spend with their both parents. Emery puts this on at least $25 \%$ independent of how the days and nights in a month are divided among the two parental homes. Whether equal time sharing or specific schedules are more or less beneficial is currently unknown in the literature. The second part of the chapter summarizes the insights from studies that look at how children fare in SPC situations. Also here, Emery concludes that a lot of work needs to be done. There is not enough evidence yet to determine the benefit of SPC versus sole custody. Four factors appear to be of importance in the outcomes for children: logistics, parental conflict, the age of the children and their personality and mental health. The chapter concludes with a plea for larger, methodologically sound studies to further develop our insights in the effects of SPC on children's wellbeing.

Building upon the work of the Commission on European Family Law (CEFL), Boele-Woelki presents in Chapter 4 an overview of comparative legal work regarding parental responsibilities. In total 39 principles regarding Parental Responsibilities have been gathered by 26 legal experts. The definition of parental responsibilities is a broad one encompassing both taking care of the child's person and its property. The parental duties stretch from the birth of a child to the child reaching majority, without determining a fixed upper age limit. From the parent's perspective, not only the two biological parents are holders of the parental responsibilities. Also other persons and public bodies can be attributed parental responsibilities which could results in more than just two persons exercising these responsibilities. The (romantic) relationship or (absence of) the legal bond between the parents should have no influence in the joint execution of parental responsibilities by both parents. Parents can make agreements on the shared exercise of the responsibilities and in case of disagreement see an external authority decide about them. In these cases, alternative conflict resolution procedures should be available to parents in order to solve their disagreement. The CEFL principles are presented as a frame of reference for national legislators.

Switzerland is seeing rapid changes in family life after divorce. For the first time, Recksiedler and Bernardi present an insight in the distribution of SPC among Swiss parents. A second focus in Chapter 5 concerns the correlates of having children in SPC and the parent's health. The share of SPC arrangements in Switzerland turned out to be quite low (11\%) and when looking at a 50-50 division, only $6.5 \%$ of all post-divorce families share the children in an equal way. There was an overrepresentation of higher educated parents and older children residing in the Swiss SPC families. With respect to health, the authors report that custody arrangements are neither associated with better physical health, nor with higher levels of emotional wellbeing. Economic factors like labour market attachment and financial situation 
turned out to be strong predictors of the parent's health situation. For gender, a surprising negative effect on SPC father's health was observed. The conclusion therefore leads to the observation that parents in SPC are neither healthier, nor happier. The high labour market attachment and the lower educational level might explain these results, as well as the overall burden of combining work and family life among the Swiss forerunners in SPC.

Is the father-child relationship quality related to the living arrangement of the children? That is the central research question in Chapter 6. Vrolijk and Keizer consider self-selection as an important factor that drives previous results in this domain. By controlling for interparental conflict before the divorce and SES, the potential self-selecting influences on the linkage between living arrangement and the quality of the father-child relationship are strongly reduced. As mediating factors, the authors take father involvement and the co-parental relationship into account. The results show that living in SPC indeed has a positive effect on the father-child relationship (even though the amount of time is unrelated to this link). The effect was mediated by parental involvement and (to a lesser degree) by the co-parental relationship. The sex of the child also played a role in that the father-son relationship was more easily influenced in SPC than the father-daughter one. The results are strengthened by the fact that the Divorce in Flanders multi-actor data allowed to perform the analyses both from the father's and from the child's perspective. The two perspectives were not always in accordance with each other but the use of both perspectives allowed to explore the complexity of the father-child relationship, and its link with children's living arrangements, to a greater extent.

Chapter 7, by Claessens and Mortelmans taps into pre- and post-separation life courses of men and women formerly living as a nuclear family with common children and specifically focuses on three postseparation dynamics affecting changes in the type of children's custody arrangements: financial position, labour force participation and repartnering. One of the most interesting gendered effects is that produced by union dynamics on custody choices. While repartnering fathers tend to drop out of SPC, repartnering mothers join in the SPC group. While apparently different, these are movements of the same kind because for both men and women repartnering translates in less time with their own biological children, fathers because the shift from SPC to sparser visiting rights and mothers because they move out of lone parenthood and sole custody towards SPC. The authors optimistically conclude that their results show some evidence of a ideational shift towards more egalitarian parenting preferences given that higher income from men and higher labour force participation for women, indicator of higher bargaining power, are not any longer predictive of higher shares of custody but rather of SPC.

Merla, Dedonder, Nobels and Murru in Chapter 8 address the underexplored question of the sense of home for children experiencing shared custody arrangements. Post-divorce arrangements where children alternate between two distinct family dwellings challenge the nuclear family ideal of home and raise questions about whether the sense of belonging and identity of such children is challenged by such complex family configurations. The authors discuss the theoretical impetus underlying such question and develop a parsimonious survey instrument, The Sense 
of Home Instrument (SOHI), to capture material and behavioural-relational dimensions of children' sense of home, by measuring the level of material comfort, the quality of parent-child relations, the level of conflict between ex-partners, and the continuity of communication across households. On the basis of survey data from Belgium, they then illustrate its validity and propose it as a useful tool to test new hypotheses on the consequences of divorce and separation for children.

The socioeconomic gradient in SPC arrangements is the focus of Chapter 9. The chapter uses two repeated cross section datasets from the Spanish and the Swedish Health Behavior of School Children (HBSC) by the World Health Organisation. The paper compares the changes in socioeconomic gradient of SPC over time and across welfare states. Garriga, Bernardi and Turunen test two competing hypotheses. First, the diffusion hypothesis that states that SPC will spread among all social strata given the changes in family law incrementally favouring the view that SPC is the preferred arrangement for children to grow up after parental separation. Second, the diverging destinies hypothesis that states that union dissolutions are increasingly socially stratified, with higher strata separating to a lesser degree than lower classes. Since SPC arrangements are more expensive than sole custody, such social difference in the likelihood to separate might make SPC even more selective among higher social classes who can afford it. The authors test both hypotheses while considering also the difference between former cohabiters versus married couples as well as the influence of the welfare state in Spain and in Sweden. The results show that the diffusion hypothesis seems to correspond to the Spanish trends in SPC while in Sweden is rather the diverging destinies hypothesis, with little or no diffusion across social strata across time, that is closer to the data. The authors conclude that the role of legal institutions regulating SPC might have been so far underestimated in social research.

In Chapter 10, by Poortman the main focus is on the role of the interplay between geographical distance between parents' home, the frequency of home-commuting and the parent child contact on a variety of children outcomes: psychological wellbeing, social integration and educational performance. Drawing on the original Dutch data from the New Families in the Netherlands Survey, the author finds differential effects of the interaction of various aspects of post separation arrangements not only depending of the outcome but also on the kind of interaction between such aspects. For instance, a frequent parent child contact (either because of SPC or because of frequent father visitations) improve the psychological wellbeing of children only in cases in which the commuting time and frequency between parents' home is lower, calling for a more nuanced understanding of what arrangements are more or less disruptive for children of separation and divorce. Shared physical custody and frequent commutes may be positive for children if parents live sufficiently close to each other.

The contribution by Hachet, in Chapter 11 analyses the negotiation process leading to shared physical custody arrangements in France around the 2002 law that begins to regulate SPC in the country. Making use of the exceptional data of the French National Funds for Family Allowances data, he shows that the large majority of couples separating agree on SPC and do not need any external intervention while 
in one third of the cases either SPC issues from a court decision or it is the result of a mediation operated by third parties like the children themselves, the judges or the family mediators. The qualitative analyses of 55 in-depth interviews of parents who equally share their children's custody result in a fine picture of who, for what reasons request shared physical custody in cases of disagreement and under which conditions. Even more interestingly, the Chapter discusses the majority of "obvious agreements", which seem to be related to the history of the relationship (e.g the pre-separation division of tasks within the couple) and of its breakup (e.g. having initiated separation makes the responsible partner more vulnerable and likely to accept the other's requests).

Chapter 12 by Darwiche, Eira Nunes, El Ghaziri, Imesch and Bessero is based on a developmental psychological approach to co-parenting. If coparenting is understood as the way in which parents support and undermines each other in relation to their parental duties, shared physical custody gives parents an opportunity to coparent their children after parental separation. In a first part of the Chapter, the authors identify a limited number of intervention programs that explicitly include SPC either as topic of discussion during the treatment or as an outcome of it. The second part of the Chapter illustrates, through a Swiss case study, the way in which SPC emerges during a therapy of a separating couple. The clinical case analysis shows that severe personal distress and acute suffering of the separating parents can coexist with effective coparenting. The authors conclude with a strong practiceoriented message in favour for more training of professional family therapists in matters related to legal decisions and child custody arrangements and for more concerted action between married and divorced couples therapists. Such suggestions seem crucial to support parents in raising their children in the contemporary context of complexification and fluidity of family arrangements.

Chapter 13, Walper, Entleitner-Phleps and Langmeyer aims at defining the prevalence and predictors of SPC in Germany, where this living arrangement is still "a rare exception" (5\% in 50-50\% arrangements and 10\% in 30-70\% arrangements), suggesting once more that a gendered division of labour within couple time has consequences for children custody after separation and divorce. Regression analyses on cross-sectional data indicate that mother's higher education and employment status as well as parents' short residential distance and good cooperation associate strongly with SPC when compared to sole custody. Less intuitively the level of conflict among SPC parents seems to be higher, which the authors explain by the need for more frequent interaction or by the fact that anticipating conflict on other issues these parents try to minimize by having an equal share of time with the children. The chapter ends with a call for more systematic longitudinal data collection on changing families arrangements.

In Chapter 14, Hakovirta and Skinner address the adaptation of child maintenance policies to the diffusion of SPC in an international comparative perspective. Adopting the model family approach, the study draws on original vignette data collected from topic experts in thirteen countries in 2017. The experts had to calculate the child maintenance due by parents depending on whether they have a $50 \%$ SPC arrangements versus a situation in which one parent has usual visiting 
rights and the other sole custody. Despite that countries vary according to what is the locus of formal decision about child maintenance (an administrative agency, the court, or an hybrid form of the two), no relation was found between such differences and the differences in maintenance under similar custody conditions. The result of this fine-grained comparison shows that there is no international standard practice in dealing with SPC maintenance policies, with most countries providing a partial reduction in the amount child maintenance if custody is shared equally, one third requiring no obligation to maintenance even in case of different parental incomes, and only two countries not offering any reduction of maintenance duties despite equal custody time. The study reveals the need for further collaborative investigations on the matter implying sociologists, public policy and legal scholars and well as professionals.

Acknowledgement This chapter benefited from the support of the Centre for Population, Family and Health (CPFH) at the University of Antwerp which enabled Open Access. This publication benefited from the support of the Swiss National Centre of Competence in Research LIVES Overcoming vulnerability : Life course perspectives. (NCCR LIVES), which is financed by the Swiss National Science Foundation (grant number : 51NF40-185901). The authors are grateful to the Swiss National Science Foundation for its financial assistance.

\section{References}

Amato, P. R. (2000). The consequences of divorce for adults and children. Journal of Marriage and Family, 62(4), 1269-1287. https://doi.org/10.1111/j.1741-3737.2000.01269.x.

Amato, P. R. (2010). Research on divorce: Continuing trends and new developments. Journal of Marriage and Family, 72(3), 650-666. https://doi.org/10.1111/j.1741-3737.2010.00723.x.

Amato, P. R., \& Cheadle, J. (2005). The long reach of divorce: Divorce and child well-being across three generations. Journal of Marriage and Family, 67(1), 191-206. https://doi.org/10.1111/j. 0022-2445.2005.00014.x.

Bartova, A., \& Keizer, R. (2020). How well do European child-related leave policies support the caring role of fathers? In R. Nieuwenhuis \& W. van Lancker (Eds.), Handbook of family policy (pp. in press). Palgrave.

Bastaits, K., \& Mortelmans, D. (2016). Parenting as mediator between post-divorce family structure and children's well-being. Journal of Child and Family Studies, 25(7), 2178-2188. https://doi. org/10.1007/s10826-016-0395-8.

Bastaits, K., \& Pasteels, I. (2019). Is joint physical custody in the best interests of the child? Parentchild relationships and custodial arrangements. Journal of Social and Personal Relationships, 36(11-12), 3752-3772. https://doi.org/10.1177/0265407519838071.

Bastaits, K., Pasteels, I., \& Mortelmans, D. (2018). How do post-divorce paternal and maternal family trajectories relate to adolescents' subjective well-being? Journal of Adolescence, 64, 98-108. https://doi.org/10.1016/j.adolescence.2018.02.005.

Baude, A., Pearson, J., \& Drapeau, S. (2016). Child adjustment in joint physical custody versus sole custody: A meta-analytic review. Journal of Divorce \& Remarriage, 57(5), 338-360. https:// doi.org/10.1080/10502556.2016.1185203.

Baude, A., Drapeau, S., Lachance, V., \& Ivers, H. (2019). Adjustment of children in joint custody and associated variables: A systematic review. Journal of Child Custody, 16(4), 313-338. https://doi.org/10.1080/15379418.2019.1691106. 
Bauserman, R. (2012). A meta-analysis of parental satisfaction, adjustment, and conflict in joint custody and sole custody following divorce. Journal of Divorce \& Remarriage, 53(6), 464-488. https://doi.org/10.1080/10502556.2012.682901.

Bergström, M., Fransson, E., Hjern, A., Köhler, L., \& Wallby, T. (2014). Mental health in Swedish children living in joint physical custody and their parents' life satisfaction: A cross-sectional study. Scandinavian Journal of Psychology, 55(5), 433-439. https://doi.org/10.1111/sjop. 12148 .

Bernardi, L., \& Mortelmans, D. (Eds.). (2018). Lone parenthood in the life course. Springer. https:// doi.org/10.1007/978-3-319-63295-7

Bjarnason, T., \& Arnarsson, A. (2011). Joint physical custody and communication with parents: A cross-national Study of children in 36 Western countries. Journal of Comparative Family Studies, 42(6). https://doi.org/10.2307/41604494.

Braver, S. L., \& Votruba, A. M. (2018). Does joint physical custody “cause" children's better outcomes? Journal of Divorce \& Remarriage, 59(5), 452-468. https://doi.org/10.1080/ 10502556.2018.1454203.

Carlsund, Å., Eriksson, U., Löfstedt, P., \& Sellström, E. (2012). Risk behaviour in Swedish adolescents: Is shared physical custody after divorce a risk or a protective factor? European Journal of Public Health, 23(1), 3-8. https://doi.org/10.1093/eurpub/cks011.

Cashmore, J., Parkinson, P., Weston, R., Patulny, R., Redmond, G., Qu, L., Baxter, J., Rajkovic, M., Sitek, T., \& Katz, I. (2010). Shared care parenting arrangements since the 2006 family law reforms: Report to the Australian government attorney-general's department. Social Policy Research Centre, University of New South Wales. https://www.arts.unsw.edu.au/sites/default/ files/documents/2_AG_Shared_Care.pdf

Cheadle, J. E., Amato, P. R., \& King, V. (2010). Patterns of nonresident father contact. Demography, 47(1), 205-225. https://doi.org/10.1353/dem.0.0084.

Cummings, E. M., \& Davies, P. T. (2010). Marital conflict and children: An emotional security perspective. New York: Guilford Press.

Fabricius, W. V., \& Luecken, L. J. (2007). Postdivorce living arrangements, parent conflict, and long-term physical health correlates for children of divorce. Journal of Family Psychology, 21 (2), 195-205. https://doi.org/10.1037/0893-3200.21.2.195.

Fransson, E., Turunen, J., Hjern, A., Ostberg, V., \& Bergstrom, M. (2016). Psychological complaints among children in joint physical custody and other family types: Considering parental factors. Scandinavian Journal of Public Health, 44(2), 177-183. https://doi.org/10.1177/ 1403494815614463.

Garriga, A., \& Bernardi, L. (2019). Custody arrangements and social inequalities among children. Revue des politiques sociales et familiales, 131-132, 207-221.

Goldscheider, F. K., Bernhardt, E., \& Lappegård, T. (2015). The gender revolution: A framework for understanding changing family and demographic behavior. Population and Development Review, 41(2), 207-239. https://doi.org/10.1111/j.1728-4457.2015.00045.x.

Goode, W. J. (1962). Marital satisfaction and instability. A cross-cultural class analysis of divorce rates. In R. Bendix \& S. M. Lipset (Eds.), Class, status, and power. Social stratification in comparative perspective (pp. 377-387). New York: The Free Press.

Goode, W. J. (1963). World revolution and family patterns. New York: Free Press Glencoe.

Goubau, D. (2009). L'évolution de la place de l'enfant au sein du droit de la famille séparée au Canada. In FAJEF \& AIFI (Eds.), Du droit de l'enfant à l'intérêt de la famille séparée (pp. 1-20). Toronto: Éditions Yvon Blais.

Guidubaldi, J., \& Perry, J. D. (1985). Divorce and mental health sequelae for children: A two-year follow-up of a nationwide sample. Journal of the American Academy of Child Psychiatry, 24(5), 531-537.

Härkönen, J., Bernardi, F., \& Boertien, D. (2017). Family dynamics and child outcomes: An overview of research and open questions [article]. European Journal of Population, 33(2), 163-184. https://doi.org/10.1007/s10680-017-9424-6. 
Harris-Short, S. (2010). Resisting the march towards 50/50 shared residence: Rights, welfare and equality in post-separation families. Journal of Social Welfare and Family Law, 32(3), 257-274. https://doi.org/10.1080/09649069.2010.520519.

Hochschild, A., \& Machung, A. (1989). The second shift: Working families and the revolution at home. New York: Penguin.

Hook, J. L. (2016). Care in context: Men's unpaid work in 20 countries, 1965-2003. American Sociological Review, 71(4), 639-660. https://doi.org/10.1177/000312240607100406.

Klünder, N., \& Meier-Gräwe, U. (2018). Caring, Cooking, Cleaning - repräsentative Zeitverwendungsmuster von Eltern in Paarbeziehungen. Zeitschrift fur Familienforschung, 30 (1), 9-29. https://doi.org/10.3224/zff.v30i1.02.

Kruk, E. (2012). Arguments for an equal parental responsibility presumption in contested child custody. The American Journal of Family Therapy, 40(1), 33-55. https://doi.org/10.1080/ 01926187.2011.575344.

Kruyfhooft, M., \& Mortelmans, D. (2011). Gezin en arbeid in je eentje: combinatiestrategieën van alleenstaande moeders en vaders. Tijdschrift voor arbeidsvraagstukken, 27(4), 487-506.

Lamb, M. E., \& Kelly, J. B. (2001). Using the empirical literatureto guide the development of parenting plans for young children. Family Court Review, 39(4), 365-371. https://doi.org/10. 1111/j.174-1617.2001.tb00618.x.

Maccoby, E. E., Buchanan, C. M., Mnookin, R. H., \& Dornbusch, S. M. (1993). Postdivorce roles of mothers and fathers in the lives of their children. Journal of Family Psychology, 7(1), 24-38. https://doi.org/10.1037/0893-3200.7.1.24.

Main, M., Hesse, E., \& Hesse, S. (2011). Attachment theory and research. Overview with suggested aplications to child custody. Family Court Review, 49(3), 426-463. https://doi.org/10.1111/j. 1744-1617.2011.01383.x.

Markham, M. S., \& Coleman, M. (2012). The good, the bad, and the ugly: Divorced mothers' experiences with coparenting. Family Relations, 61(4), 586-600. https://doi.org/10.1111/j. 1741-3729.2012.00718.x.

Meyer, D. R., Cancian, M., \& Cook, S. T. (2017). The growth in shared custody in the United States: Patterns and implications. Family Court Review, 55(4), 500-512. https://doi.org/10. $1111 /$ fcre. 12300.

Nielsen, L. (2014a). Parenting plans for infants, toddlers, and preschoolers: Research and issues. Journal of Divorce \& Remarriage, 55(4), 315-333. https://doi.org/10.1080/10502556.2014. 901857.

Nielsen, L. (2014b). Shared physical custody: Summary of 40 studies on outcomes for children. Journal of Divorce \& Remarriage, 55(8), 613-635. https://doi.org/10.1080/10502556.2014. 965578.

Nielsen, L. (2014c). Woozles: Their role in custody law reform, parenting plans, and family court. Psychology, Public Policy, and Law, 20(2), 164-180. https://doi.org/10.1037/law0000004.

Nielsen, L. (2015). Shared physical custody: Does it benefit most children. Journal of the American Academy of Matrimonial Lawyers, 28, 79-138.

Nielsen, L. (2017). Re-examining the research on parental conflict, coparenting, and custody arrangements. Psychology, Public Policy, and Law, 23(2), 211-231. https://doi.org/10.1037/ law0000109.

Nielsen, L. (2018a). Joint versus sole physical custody: Children's outcomes independent of parent-child relationships, income, and conflict in 60 studies. Journal of Divorce \& Remarriage, 59(4), 247-281. https://doi.org/10.1080/10502556.2018.1454204.

Nielsen, L. (2018b). Joint versus sole physical custody: Outcomes for children independent of family income or parental conflict. Journal of Child Custody, 15(1), 35-54. https://doi.org/10. 1080/15379418.2017.1422414.

Poortman, A.-R. (2018). Postdivorce parent-child contact and child well-being: The importance of predivorce parental involvement. Journal of Marriage and Family, 80(3), 671-683. https://doi. org/10.1111/jomf.12474. 
Schoppe-Sullivan, S. J., \& Fagan, J. (2020). The evolution of fathering research in the 21st century: Persistent challenges, new directions. Journal of Marriage and Family, 82(1), 175-197. https:// doi.org/10.1111/jomf.12645.

Smyth, B. M. (2017). Special issue on shared-time parenting after separation. Family Court Review, 55(4), 494-499. https://doi.org/10.1111/fcre.12299.

Sobolewski, J. M., \& Amato, P. R. (2007). Parents' discord and divorce, parent-child relationships and subjective well-being in early adulthood: Is feeling close to two parents always better than feeling close to one? Social Forces, 85(3), 1105-1124. https://doi.org/10.1353/sof.2007.0056.

Sodermans, A. K., Matthijs, K., \& Swicegood, G. (2013). Characteristics of joint physical custody families in Flanders [Article]. Demographic Research, 28, 821-848, Article 29. https://doi.org/ 10.4054/DemRes.2013.28.29

Sodermans, A. K., Botterman, S., Havermans, N., \& Matthijs, K. (2015). Involved fathers, liberated mothers? Joint physical custody and the subjective well-being of divorced parents. Social Indicators Research, 122(1), 257-277. https://doi.org/10.1007/s11205-014-0676-9.

Solomon, J., \& George, C. (1999). The effects on attachment of overnight visitation on divorced and separated families: A longitudinal follow up. In J. Solomon \& C. George (Eds.), Attachment disorganization in atypical populations (pp. 243-264). New York: Guilford Press.

Spruijt, E., \& Duindam, V. (2002). Was there an increase in caring fatherhood in the 1990s? Two Dutch longitudinal studies. Social Behavior and Personality: An International Journal, 30(7), 683-695. https://doi.org/10.2224/sbp.2002.30.7.683.

Spruijt, E., de Goede, M., \& Vandervalk, I. (2004). Frequency of contact with nonresident fathers and adolescent well-being: A longitudinal analysis. Journal of Divorce \& Remarriage, 40(3-4), 77-90. https://doi.org/10.1300/J087v40n03_05.

Steinbach, A. (2019). Children's and parents' well-being in joint physical custody: A literature review. Family Process, 58(2), 353-369. https://doi.org/10.1111/famp.12372.

Steinbach, A., Augustijn, L., \& Corkadi, G. (2020). Joint physical custody and adolescents' life satisfaction in 37 North American and European countries. Family Process. https://doi.org/10. 1111/famp.12536.

Thevenon, O. (2011). Family policies in OECD countries: A comparative analysis. Popululation and Development Review, 37(1), 57-87. https://doi.org/10.1111/j.1728-4457.2011.00390.x.

Turunen, J. (2017). Shared physical custody and children's experience of stress. Journal of Divorce \& Remarriage, 58(5), 371-392. https://doi.org/10.1080/10502556.2017.1325648.

van der Heijden, F., Poortman, A.-R., \& van der Lippe, T. (2016). Children's postdivorce residence arrangements and parental experienced time pressure. Journal of Marriage and Family, 78(2), 468-481. https://doi.org/10.1111/jomf.12283.

van der Wiel, R., Mulder, C. H., \& de Valk, H. A. G. (2020). From living apart to living together: Do children born before the current partnership matter? Comparative Population Studies, 45, 115-142. https://doi.org/10.12765/CPoS-2020-07en.

Warshak, R. A. (2018). Night shifts: Revisiting blanket restrictions on children's overnights with separated parents. Journal of Divorce \& Remarriage, 59(4), 282-323. https://doi.org/10.1080/ 10502556.2018.1454193.

Westphal, S. K., Poortman, A.-R., \& van der Lippe, T. (2014). Non-resident father-child contact across divorce cohorts: The role of father involvement during marriage. European Sociological Review, 30(4), 444-456. https://doi.org/10.1093/esr/jcu050. 
Laura Bernardi is Full Professor of Life Course Demography and Sociology at the University of Lausanne and President of the Social Sciences and Humanities Division of the Swiss National Research Foundation. She is also Associate Editor and former co-Editor in Chief of the journal Advances in Life Course Research and of the Springer book series Life Course and Social Policies. Her research interests are in the field of life course sociology and family demography. Her publications range from the cultural determinants of fertility and family behaviours, the role of social influence on fertility and family transitions to spillover and crossover processes in the life course and their effects on wellbeing. She has extensively published in a wide range of peerreviewed articles in international journals, in the field of demography, sociology and gender, contributed several chapters in collective volumes and has co-edited the books Lone parenthood in the Life Course (Springer); Situating Children of Migrants (Springer); The Demography of Europe (Springer).

Dimitri Mortelmans is Full Professor of Sociology at the Faculty of Political and Social Sciences of the University of Antwerp, Belgium. He is head of the Centre for Population, Family, and Health $(\mathrm{CPFH})$. His research concentrates on family sociology and sociology of labour. He has published on divorce, new constituted families, gendered labour careers and work-life balance. He is also the main author of the Step in Statistics book series of which six volumes have been published (in Dutch). On qualitative methodology, he published the Handbook of Qualitative Research Methods and Qualitative Analysis with NVivo. In demography, he (co-)edited Changing Family Dynamics and Demographic Evolution. The Family Kaleidoscope (Edward Elgar), Lone parenthood in the Life Course (Springer) and Divorce in Europe (Springer).

Open Access This chapter is licensed under the terms of the Creative Commons Attribution 4.0 International License (http://creativecommons.org/licenses/by/4.0/), which permits use, sharing, adaptation, distribution and reproduction in any medium or format, as long as you give appropriate credit to the original author(s) and the source, provide a link to the Creative Commons license and indicate if changes were made.

The images or other third party material in this chapter are included in the chapter's Creative Commons license, unless indicated otherwise in a credit line to the material. If material is not included in the chapter's Creative Commons license and your intended use is not permitted by statutory regulation or exceeds the permitted use, you will need to obtain permission directly from the copyright holder.

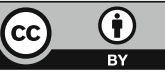

